\title{
Physico-chemical changes of Kujithekera (Garcinia cowa Roxb.) fruit during storage
}

\author{
- S. Dutta ${ }^{1}$ and M. Neog ${ }^{2 *}$ \\ ${ }^{1}$ Department of Horticulture, Assam Agricultural University, Jorhat (Assam) India \\ ${ }^{2}$ Directorate of Extension Education, Assam Agricultural University, Jorhat (Assam) India
}

*Author for Correspondence

Research chronicle : Received : 15.12.2017; Revised : 17.05.2018; Accepted : 25.05.2018

\begin{abstract}
SUMMARY:
Kujithekera (Garcinia cowa Roxb), commonly known as Cowa is a sub-tropical minor fruit grows well in Assam. Fruits are juicy having sub-acid taste and suitable for preparation of jam and pickles, sundried slices given in dysentery as medicine. An attempt was made to understand the changes in physico-chemical qualites of Kujithekera fruit during storage at ambient temperature (Mean temp $29.8^{\circ} \mathrm{C}$, Mean RH 79.6\%) for 6 days at an interval of two days. The physico-chemical changes of the fruit during storage using five different treatments were studied. There was significant increase in physiological loss in weight with advancement of storage period. The bio-chemical qualities of the treated fruits like TSS, crude protein, fat, ash were found to decrease significantly with the advancement of storage period. The fruits treated with 1 per cent wax emulsion retained the highest TSS, both in pulp and peel on 6 days after storage. The fruit pulp qualities like crude protein, fat, ash, total phenl were almost same in wax coated fruits and $\mathrm{CaCl}_{2}$ treated fruits on 6 days after storage.
\end{abstract}

KEY WORDS : Kujithekera, Garcinia cowa Roxb, Physico-chemical, Wax emulsion

How to cite this paper: Dutta, S. and Neog, M. (2018). Physico-chemical changes of Kujithekera (Garcinia cowa Roxb.) fruit during storage. Internat. J. Proc. \& Post Harvest Technol., 9 (1) : 21-27. DOI: 10.15740/ HAS/IJPPHT/9.1/21-27. Copyright@ 2018: Hind Agri-Horticultural Society. 